\title{
KAP study on cervical cancer and human papillomavirus vaccine acceptability among adolescent girls of Eastern UP: a cross sectional study
}

\author{
Seema Kumari ${ }^{1}$, Aradhana Singh ${ }^{1 *}$, Renu Sangal ${ }^{2}$, Neela R. Sharma ${ }^{1}$
}

\begin{abstract}
Department of Obstetrics and Gynecology, BRD Medical College, Gorakhpur, Uttar Pradesh, India Department of Obstetrics and Gynecology, MVAS Medical College, Basti, Uttar Pradesh, India
\end{abstract}

Received: 28 February 2021

Accepted: 06 April 2021

\author{
*Correspondence: \\ Dr. Aradhana Singh, \\ E-mail: aradhanamdobg@gmail.com
}

Copyright: (C) the author(s), publisher and licensee Medip Academy. This is an open-access article distributed under the terms of the Creative Commons Attribution Non-Commercial License, which permits unrestricted non-commercial use, distribution, and reproduction in any medium, provided the original work is properly cited.

\begin{abstract}
Background: Human papillomavirus (HPV) is the most common sexually transmitted infection and is a causal factor for cervical cancer in virtually $100 \%$ cases. Despite the availability of highly effective vaccine against HPV, the burden of this dreaded disease remains high in our country. The aim of this study was to study the knowledge, attitude and practices on cervical cancer and HPV vaccine among adolescent girls of Eastern UP and to study the factors influencing knowledge, attitude and practices towards HPV vaccination among adolescent girls of this region.

Methods: This was a questionnaire based cross-sectional study. Purposive sampling was used. Sample consisted of adolescent girls attending Gynecological OPD of a tertiary care center of Eastern UP, for a period of one year and the sample size was 384 .

Results: The results showed that, only $8.07 \%$ participants had heard of HPV infection and $2.08 \%$ participants had HPV vaccine knowledge. 35.95\% participants agreed that their parents would pay for vaccine and $79.17 \%$ participants agreed for vaccination, if it would be free of cost. In total, most of the participants in the sample were found to have a positive attitude towards the vaccine.

Conclusions: Although the knowledge and awareness of cervical cancer and its prevention through HPV vaccination, was poor among adolescent girls of Eastern UP region, it was encouraging to find, that most of them had a positive attitude towards HPV vaccination. It was also concluded, that the acceptability would increase, if the Government includes HPV vaccination in the National Immunization Program. If the cost constraint is dealt with, this completely preventable disease could be controlled in our country.
\end{abstract}

Keywords: Cervical cancer, HPV vaccination, Human Papillomavirus, KAP

\section{INTRODUCTION}

HPV is the most common sexually transmitted infection and is the causal factor for development of carcinoma cervix in virtually $100 \%$ cases. ${ }^{1}$ Cervical cancer is the second most common gynaecological malignancy amongst Indian women, after carcinoma breast (annual crude incidence rate is 14.9 and 24.9 per 100,000 women per year respectively). ${ }^{2,3}$ The age standardized incidence rate for cervical cancer in Indian women is 22 per 100,000 women per year, which is the highest in south Asia. ${ }^{4} \mathrm{HPV}$ is also causative factor in $78 \%$ vaginal cancers, $15-48 \%$ of valval cancers and $88 \%$ of anal cancers. ${ }^{5}$

The impressive fact is that, HPV infection and thus cervical cancer, is totally preventable through vaccination. It is now well established through clinical 
trials, that HPV vaccine is $100 \%$ effective against cervical high-grade lesions, when administered to HPV naive girls of 15 to 26 years age. Clinical protection and antibody titre were sustained over 8 to 10 years. ${ }^{6}$

HPV prevalence in cervical specimen ranged from $1.6 \%$ in developed countries, to $41.9 \%$ in developing countries. Age specified prevalence peaked at less than 25 years of age, with prevalence of $21.8 \%-24 \%$, with lower prevalence at middle age.

Following HPV infection, the development of carcinoma cervix can take 20 years or more. The high-grade precancerous lesions usually develop in less than 5 years after infection and in clinical trials, these lesions are widely accepted as clinical end points, in inferring vaccine efficacy against invasive carcinoma cervix. ${ }^{7}$

HPV type 16 and 18 are the most frequent types worldwide, with HPV 16 being the commonest type, in all regions.

Three prophylactic vaccines, directed against high risk HPV types, are currently available and marketed in many countries, including India, for prevention of HPV related cancers. All these vaccines are intended to be administered before the onset of sexual activity, that is, before the first exposure to HPV infection. Highest immune response is observed in girls of 9-15 years age.

Antibody titre remained high for at least 10 years for bivalent vaccine (with $100 \%$ seropositivity), for at least 9.9 years for quadrivalent vaccine and for at least 5 years for nonavalent vaccine. ${ }^{8,9}$

According to a recent ICMR finding, despite the availability of HPV vaccine in our country, deaths due to cervical cancer, has increased rapidly during the last 2 years. ${ }^{10}$

This is probably because of almost non-existent primary prevention, combined with, late detection and unavailable or unaffordable secondary prevention and treatment. Also, lack of awareness and less acceptability of preventive modality, including vaccination, is a big compounding factor in prevention of this disease in our country.

\section{Justification}

In spite of being almost completely vaccine preventable disease, the incidence and mortality due to cervical cancer remains very high in our country. This study was conducted to assess the awareness and knowledge about cervical cancer and acceptability of HPV vaccine among adolescent girls, of Eastern UP. No such study has been previously conducted in this region.

The aim of this study was to assess knowledge, attitude and practices on cervical cancer and HPV vaccine among adolescent girls and to study the factors influencing knowledge, attitude and practices towards HPV vaccination, among adolescent girls of Eastern UP.

\section{METHODS}

This was a questionnaire based, cross sectional study. Adolescent girls of 10 to 19 years of age, attending, outpatient gynecology department of BRD medical college, Gorakhpur, UP, India, over a period of one year (July 2015 to June 2016) and giving consent, were included in this study, after verbal explanation of the objective and the general nature and purpose of the study.

Critically ill women, mentally challenged women and those not giving consent were excluded from the study.

Sample size was calculated using the formula, $\mathrm{n}=4 \mathrm{pq} / 12=384$. Sampling technique was purposive sampling.

A predesigned questionnaire was used. The questionnaire was designed in Hindi, based on extensive review of published literatures.

It was validated by 'pilot testing' and ideas for improvement was incorporated into the questionnaire. The questionnaire enquired about the awareness of cervical cancer and HPV vaccine, causative relationship of HPV with cervical cancer, effectiveness and acceptance of HPV vaccine. ${ }^{11}$

The awareness about cervical cancer was investigated among all participants. Those who had heard about cervical cancer were further asked about awareness of the disease burden in our country and about its causal relationship with HPV.

We enquired, whether they thought that cervical cancer was preventable and if they knew about HPV vaccine. We also tried to assess vaccine acceptability among the participants. They were asked, whether the inclusion of HPV vaccine in Government sponsored immunization program, would increase its acceptability. "Likert rating scale" was used, to rate and analyze the responses.

Each response was rated with integer value 1, for strongly disagree to 5 , for strongly agree. ${ }^{12}$ The participants were assured of confidentiality. SPSS version 21 was used for statistical analysis.

\section{RESULTS}

As shown in Table 1, the majority of the study participants $(49.74 \%)$ were in 17 to 19 years age group. Mean age of the study population was $16.8 \pm 2.9$ years.

Most $(81.78 \%)$ participants belonged to rural background and only $26.04 \%$ participants were educated up to class $12^{\text {th }}$. 
Table 1: Socio demographic profile of the participants.

\begin{tabular}{|lll|}
\hline Age (years) & Number $(\mathbf{N}=384)$ & Percentage $(\%)$ \\
\hline $10-13$ & 58 & 15.10 \\
\hline $14-16$ & 135 & 35.16 \\
\hline $17-19$ & 191 & 49.74 \\
\hline Background & & \\
\hline Rural & 314 & 81.78 \\
\hline Urban & 70 & 18.22 \\
\hline Education (Participants) & \\
\hline \multicolumn{1}{|c|}{ Illiterate } & 59 & 15.37 \\
\hline \multicolumn{1}{|c|}{$8^{\text {th }}$} & 62 & 16.14 \\
\hline \multicolumn{1}{|c|}{$10^{\text {th }}$} & 80 & 20.84 \\
\hline \multicolumn{1}{|c|}{$12^{\text {th }}$} & 100 & 26.04 \\
\hline Graduation & 83 & 21.69 \\
\hline Socio economic & status & 02.83 \\
\hline Upper class & 8 & 20.83 \\
\hline $\begin{array}{l}\text { Upper middle } \\
\text { class }\end{array}$ & 80 & 34.11 \\
\hline Middle class & 131 & 32.81 \\
\hline $\begin{array}{l}\text { Lower middle } \\
\text { class }\end{array}$ & 126 & 9.42 \\
\hline Lower class & 39 & \\
\hline
\end{tabular}

Table 2: Knowledge of HPV infection among the participants.

\begin{tabular}{|lll|}
\hline $\begin{array}{l}\text { Knowledge of } \\
\text { HPV Infection }\end{array}$ & Number $(\mathbf{N})$ & Percentage (\%) \\
\hline Yes & 31 & 08.07 \\
\hline No & 353 & 91.93 \\
\hline Total & 384 & 100 \\
\hline
\end{tabular}

As shown in Table 2, the majority of the participants $(91.93 \%)$ had never heard about HPV infection.

Table 3: Source of knowledge of HPV.

\begin{tabular}{|ll|}
\hline Source of Knowledge & HPV \\
\hline News Paper & $0(0.0 \%)$ \\
\hline Radio & $0(0.0 \%)$ \\
\hline TV & $5(16.12 \%$ \\
\hline Internet & $0(0.0 \%)$ \\
\hline Books & $25(80.64 \%)$ \\
\hline Health Worker & $1(3.22 \%)$ \\
\hline Friends & $0(0.0 \%)$ \\
\hline Relatives & $0(0.0 \%)$ \\
\hline Magazine & $0(0.0 \%)$ \\
\hline Total & 31 \\
\hline
\end{tabular}

As shown in Table 3, the most common source of information about HPV infection was through books $(80.64 \%)$.

As shown in Table 4, most of the participants (97.92\%) did not know about HPV vaccine.
Table 4: Knowledge of HPV Vaccine.

\begin{tabular}{|lll|}
\hline $\begin{array}{l}\text { Knowledge of } \\
\text { HPV vaccine }\end{array}$ & Number $(\mathbf{N})$ & Percentage $(\%)$ \\
\hline Yes & 8 & 2.08 \\
\hline No & 376 & 97.92 \\
\hline Total & 384 & 100 \\
\hline
\end{tabular}

Table 5: Questionnaire based response of the participants.

\begin{tabular}{|c|c|c|}
\hline Questions & $\begin{array}{l}\text { Yes } \\
\mathbf{N}(\%)\end{array}$ & $\begin{array}{l}\text { No } \\
\mathbf{N}(\%)\end{array}$ \\
\hline $\begin{array}{l}\text { Have you ever heard of } \\
\text { cervical cancer? }\end{array}$ & $24(6.25)$ & $\begin{array}{l}360 \\
(93.75)\end{array}$ \\
\hline $\begin{array}{l}\text { Is incidence of cervical } \\
\text { cancer high in India? }\end{array}$ & $20(5.20)$ & $\begin{array}{l}364 \\
(94.80)\end{array}$ \\
\hline $\begin{array}{l}\text { Does HPV cause } \\
\text { cervical cancer? }\end{array}$ & $29(7.55)$ & $\begin{array}{l}355 \\
(92.45)\end{array}$ \\
\hline $\begin{array}{l}\text { Does HPV spread by } \\
\text { sexual contact? }\end{array}$ & $21(5.47)$ & $\begin{array}{l}363 \\
(94.53)\end{array}$ \\
\hline $\begin{array}{l}\text { Is HPV cured by } \\
\text { medication? }\end{array}$ & $20(5.20)$ & $\begin{array}{l}364 \\
(94.80)\end{array}$ \\
\hline $\begin{array}{l}\text { Is HPV a self-limiting } \\
\text { disease? }\end{array}$ & $20(5.20)$ & $\begin{array}{l}364 \\
(94.80)\end{array}$ \\
\hline $\begin{array}{l}\text { Is HPV identified by } \\
\text { investigation? }\end{array}$ & 18 (4.69) & $\begin{array}{l}366 \\
(95.31)\end{array}$ \\
\hline $\begin{array}{l}\text { Is HPV infection } \\
\text { prevented by barrier } \\
\text { method? }\end{array}$ & $20(5.20)$ & $\begin{array}{l}364 \\
(94.80)\end{array}$ \\
\hline $\begin{array}{l}\text { Should women be } \\
\text { investigated for HPV? }\end{array}$ & $50(13.02)$ & $\begin{array}{l}334 \\
(86.97)\end{array}$ \\
\hline $\begin{array}{l}\text { Is HPV infection very } \\
\text { common? }\end{array}$ & $24(6.25)$ & $\begin{array}{l}360 \\
(93.75)\end{array}$ \\
\hline $\begin{array}{l}\text { Does HPV infection } \\
\text { cause any symptoms in } \\
\text { women? }\end{array}$ & 23 (5.99) & $\begin{array}{l}361 \\
(94.01)\end{array}$ \\
\hline $\begin{array}{l}\text { Is HPV infection } \\
\text { prevented by vaccine? }\end{array}$ & 08 (2.08) & $\begin{array}{l}376 \\
(97.91)\end{array}$ \\
\hline
\end{tabular}

As shown in Table 5, A mean population of 360.92 (93.99\%) were not aware about cervical cancer, its causative relation with HPV, spread and prevention.

As shown in Table 6, the median response, for whether, parents would pay for vaccine and whether, only sexually active should receive HPV vaccine, was "can't say" or neutral.

Median number of respondents strongly agreed to get vaccinated, if it were free of cost and were also willing to know more about HPV infection and HPV vaccination. The central tendency for the item "it's not necessary for me to get vaccinated" was "strongly disagree".

As shown in Table 7, the none of the participants were vaccinated against HPV. 
Table 6: Attitude regarding HPV vaccination.

\begin{tabular}{|c|c|c|c|c|c|}
\hline Questions & $\begin{array}{l}\text { Strongly } \\
\text { disagree }\end{array}$ & Disagree & Can't say & Agree & $\begin{array}{l}\text { Strongly } \\
\text { agree }\end{array}$ \\
\hline I think my parents would pay for the vaccine & $\begin{array}{l}20 \\
(5.2 \%)\end{array}$ & $\begin{array}{l}76 \\
(19.79 \%)\end{array}$ & $\begin{array}{l}150 \\
(39.06 \%)\end{array}$ & $\begin{array}{l}98 \\
(25.52 \%)\end{array}$ & $\begin{array}{l}40 \\
(10.43 \%)\end{array}$ \\
\hline I would get the vaccine if it were for free of cost & $\begin{array}{l}20 \\
(5.2 \%)\end{array}$ & $\begin{array}{l}10 \\
(2.6 \%)\end{array}$ & $\begin{array}{l}50 \\
(13.03 \%)\end{array}$ & $\begin{array}{l}104 \\
(27.08 \%)\end{array}$ & $\begin{array}{l}200 \\
(52.09 \%)\end{array}$ \\
\hline It's not necessary for me to get vaccinated & $\begin{array}{l}200 \\
(52.09 \%)\end{array}$ & $\begin{array}{l}104 \\
(27.08 \%)\end{array}$ & $\begin{array}{l}50 \\
(13.03 \%)\end{array}$ & $\begin{array}{l}10 \\
(2.6 \%)\end{array}$ & $\begin{array}{l}20 \\
(5.2 \%)\end{array}$ \\
\hline only sexually active women should receive the vaccine & $\begin{array}{l}68 \\
(17.70 \%)\end{array}$ & $\begin{array}{l}38 \\
(9.89 \%)\end{array}$ & $\begin{array}{l}150 \\
(39.06 \%)\end{array}$ & $\begin{array}{l}60 \\
(15.62 \%)\end{array}$ & $\begin{array}{l}64 \\
(16.66 \%)\end{array}$ \\
\hline $\begin{array}{l}\text { I wish to get more information on HPV } \\
\text { infection/HPV Vaccine }\end{array}$ & $\begin{array}{l}20 \\
(5.2 \%)\end{array}$ & $\begin{array}{l}10 \\
(2.6 \%)\end{array}$ & $\begin{array}{l}50 \\
(13.03 \%)\end{array}$ & $\begin{array}{l}100 \\
(26.04 \%)\end{array}$ & $\begin{array}{l}204 \\
(53.12 \%)\end{array}$ \\
\hline
\end{tabular}

Table 7: Vaccinated against HPV.

\begin{tabular}{|lll|}
\hline Vaccination status & Number $(\mathbf{N})$ & $\begin{array}{l}\text { Percentage } \\
(\%)\end{array}$ \\
\hline Yes & 0 & 0 \\
\hline No & 308 & 80.21 \\
\hline Don't Know & 76 & 19.79 \\
\hline Total & 384 & 100 \\
\hline
\end{tabular}

\section{DISCUSSION}

Of the total 384 women studied, majority were in 17 to 19 years age group. The mean age of the sample population was 16.8 years (SD 2.9). Most of the participants were from rural background $(81.78 \%)$ and $26.04 \%$ were educated up to class $12^{\text {th }}$.

An overwhelming majority of participants had never heard about HPV infection (91.93\%). Among those who were aware, the most common source of their information was books and television. There was minimal role of health care professionals, as a source of their knowledge, in the present study. Whereas, the most common source of information was health professional, in a study by Juntasopeepun et al, in Thailand. ${ }^{13}$

In a study by Jyoti Singh et al, at Delhi, the majority of the women surveyed (85\%), were aware of cervical cancer and among them $32.4 \%$, knew about its causal relationship with HPV and that, it was sexually transmitted. ${ }^{14}$ This contrast was probably because, $74.4 \%$ participants, were educated up to graduation or higher level in the Delhi based study, as compared to only $21.69 \%$ participants, having graduation-level education, in the present study. In a similar survey, in Karnataka, India, about $50 \%$ of the sample population was aware, that cervical cancer was sexually transmitted. ${ }^{15}$

Also, the knowledge about HPV infection and HPV vaccine was more among late age group (17 to 19 years) participants, in this study. Participants, with education level up to class $8^{\text {th }}$, had no knowledge about cervical cancer or HPV infection.
Knowledge about HPV infection and vaccine was higher among upper socioeconomic class participants.

In this study, only $7.55 \%$ women knew about the causal relationship between HPV and cervical cancer and only $5.47 \%$ were aware that it spreads by sexual contact. Also, only $2.08 \%$ women believed that, HPV infection and cervical cancer could be prevented by vaccination. Despite this poor knowledge, their attitude towards vaccination was overall positive, when they were educated about the vaccine and a majority believed that, it was necessary for them to receive the vaccine.

In this study, $35.95 \%$ participants agreed that, their parents could pay for vaccine, while $79.17 \%$ agreed for vaccination, if it were free of cost. This high acceptance rate among the surveyed population, may be due to the detailed information, the participants received about cervical cancer and HPV vaccination. In a study, CharaKorn $\mathrm{C}$. et al found, that despite poor knowledge, the acceptability of HPV vaccine was high, among the participants. ${ }^{16}$ In a similar study, by Basu and Mittal in Kolkata, it was reported that, counselling and information by health care providers, increased the acceptance of HPV vaccine. ${ }^{17}$

One of the possible reasons, of low awareness and acceptance of HPV vaccine, in our country, is its high cost. Most of the participants in the present study, felt, that the acceptance level of HPV vaccine would increase, if it were a part of the Government sponsored immunization program.

An analysis of 29 articles, based on 27 studies, in 13 different Sub-Saharan African (SSA) countries, demonstrated high rates of willingness to learn more about the vaccine and high level of acceptability of HPV vaccine, despite consistently low level of knowledge of cervical cancer, HPV and HPV vaccine. This study also reported, that a very high success rate of HPV vaccination pilot program, in six African countries, was as a result of school based, health facility based and nationwide sensitization campaigns. ${ }^{18}$ In India, Delhi was 
the first state to replicate this, setting a milestone for our country, by introducing HPV vaccination as a Public Health Program, for school children. ${ }^{19}$

The limitation of this study is that, the population studied is representative of Eastern UP and it is difficult to generalize the findings of this study, to the wider population of UP.

\section{CONCLUSION}

A majority of the women surveyed, had a poor knowledge about cervical cancer, its causal relation with HPV, its mode of transmission and prevention through HPV vaccination.

But it was encouraging to find, that most of them had a positive attitude towards HPV vaccination, when they were detailed about cervical cancer and its prevention through HPV vaccination.

This shows that introduction of a nationwide sensitization campaign, educating target population and induction of HPV vaccination in national immunization program, would facilitate awareness and acceptance of HPV vaccination in our country. Also, health care providers may play a major role to this end, by taking opportunity to educate adolescent women and their parents about cervical cancer prevention, through HPV vaccination, whenever they visit hospitals for any health-related reasons.

Unless, cost constraint is dealt with, the poor masses of our country would not be protected from this dreaded, but completely preventable disease.

Funding: No funding sources

Conflict of interest: None declared

Ethical approval: The study was approved by the Institutional Ethics Committee

\section{REFERENCES}

1. Bruni L, Albero G, Serrano B, Mena M, Gomez D, Munoz J, et al. ICO/IARC Information Centre on HPV and Cancer (HPV Information centre). Human Papillomavirus and Related Diseases in India. Summary Report 17 June 2019.

2. Ferlay J, Ervik M, Lam F, Colombet M, Mery L, Pineros M, et al. Global Cancer Observatory: Cancer Today. Lyon, France: International Agency for Research on Cancer. 2018.

3. National Centre for Disease Informatics and Research, National Cancer Registry Programme, ICMR. Time trends in cancer incidence rates, 1982-2010. Bangalore, India: NCDIR-NCRP (ICMR); 2013.
4. Kumar N A, Ramnath T, Chaturvedi M. The magnitude of cancer in India. Indian J Med Res. 2009;130(3):21921.

5. Plummer M. Global burden of cancers attributable to infections in 2012: a synthetic analysis. Lancet Glob Health. 2016;4(9):e609-16.

6. Ferris D, Samakoses R, Block S. L, et al, Long Term Study of a Quadrivalent Human Papillomavirus Vaccine, Paediatr. 2014;134(3):e657-e665.

7. Human Papillomavirus Vaccines: WHO position. 2017;19:92,241-68.

8. Schwarz TF. 10 year follow up on immunogenicity and safety of the Human Papilloma Virus 16/18 As04Adjuvanted vaccine administered to 10-4 years old girls. Abstract at WSPID 2015, Rio de Janeiro,

9. Nygard M. evaluation of the long term Anti-Human Papillomavirus 6,11, 16 and 18, Immune response Generated by the Quadrivalent HPV vaccine. Clin Vac Immuno. 2015;22(8):943-8.

10. Cervical cancer back as top killer among women. Sushmi Dey/TNN/Updated: May 4, 2016.

11. Andrade C, Menon V, Ameen S, Praharaj SK. designing and conducting knowledge, attitude and practice surveys in psychiatry: Practical guidance. Indian J Psychol Med. 2020;42(5):478-81.

12. Kyriazos TA, Stalikas A. Applied psychometrics: the steps of scale development and standardization process. Psycho. 2018;9(11):2531-60.

13. Juntasopeepun, P. Davidson, P. M. Suwan, N. Phianmongkhol et al. Human Papillomavirus Vaccination Intention among Young Women in Thailand. Asian Pacific J Can Preven. 2011;12(12):3213-9.

14. Singh J, Roy B, Yadav A. Cervical cancer awareness and HPV vaccine acceptability among females in Delhi: A cross-sectional study. Ind J Can. 2018;55(3):233-7.

15. Montgomery MP, Dune T, Shetty PK, Shetty AK. knowledge and Acceptability of Human Papillomavirus Vaccination and Cervical Cancer Screening among Women in Karnataka. Ind J Can Educ. 2015;30(1):1307.

16. Charakorn C, Rattanasiri S, Lertkhachonsuk AA Thanapprapasr D, Chittithaworn S, Wilailak S. knowledge of Pap smear, HPV and HPV vaccine and the acceptability of HPV vaccine by Thai women. AsiaPacific J Clin Onco. 2011;7(2):160-7.

17. Basu P, Sarkar S, Mukherjee S. Women's perceptions and social barriers determine compliance to cervical screening: Results from a population-based study in India. Can Detect Prev. 2016;30(4):369-74.

18. Perlman S, Wamai RG, Bain PA, Welty T, Welty E, et al. Knowledge and Awareness of HPV Vaccine and Acceptability to Vaccinate in Sub-Saharan Africa: A Systematic Review. PLoS ONE. 2014;9(3):e90912.

19. Chatterjee P.Delhi first state to launch HPV vaccine as public health programme in schools. The Indian Express. New Delhi: Indian Express Group. 2016.

Cite this article as: Kumari S, Singh A, Sangal R, Sharma NR. KAP study on cervical cancer and HPV vaccine acceptability among adolescent girls of Eastern UP: a cross sectional study. Int J Reprod Contracept Obstet Gynecol 2021;10:2031-5. 